\title{
The Effect of Concentrate Substitution with Fermented Lamtoro Leaves Flour (Leucaena glauca) in Ration on Feed Consumtion, Growth and Feed Conversion of Broiler Chicken
}

\author{
Widharto, $\mathrm{D}^{1}$. ,Risyani, $\mathrm{L}^{1}$. and R. Almaratu ${ }^{1}$. \\ ${ }^{1}$ Akademi Peternakan Karanganyar \\ Coresponding author : damaryw@ymail.com
}

\begin{abstract}
This study was conducted to determine the effect of concentrate substitution with fermented lamtoro leaves flour (Leucaena glauca) in rations onfeed consumption, growth and feed conversion of broiler chicken. A total of 60 day-old broiler chickens were divided into 4 treatments and these treatments were : Control treatment (T-0), group of chickens that were given feed concentrated feed without any substitution; The Treatment Group 1 ( T-1 ), group of chickens that were given concentrated feed that was partly replaced by Fermented Lamtoro leaves flour with 5\% concentration;and Treatment group 2 (T-2), group of chickens that were given concentrated feed that was partly replaced by Fermented Lamtoro leaves flour with 10\% concentration; and Treatment Group 3 (T-3), group of chickens that were given concentrated feed that was partly replaced by Fermented Lamtoro leaves flour with $15 \%$ concentration. Variables observed in this studywere: feed consumption, growth, and feed conversion of broiler chickens. The data that was obtained during the study from each treatment were : 1 ) feed consumptionwere 82,79 (T-0 ); 84,24 ( T-1 ); 84,01 ( T-2 ) and 82,36 gr / chicken/day (T3), 2 ) and 42,89 ( T-0 ) , 45,92 ( T-1 ), 46,13 ( T-2 ), and 42,90 gr/ (T-3) chicken/day for growth, and 3 ) 1,94 ( t0 ); 1,84 ( t1 ); 1,82 ( t2 ); and 1,92 ( t-3 ) for feed conversion. Statistical tests indicates there is no significant difference on feed consumption, growth, and feed consumption. The conclusion of the study is that the substitution of feed concentrate with lamtoro (Leucaena glauca) leaves flour fermentation does not affect feed consumption, growth, and feed conversion of broiler chickens
\end{abstract}

Keywords : Broiler Chickens, Concentrate, and Fermented Lamtoro Leaves Flour

\section{Introduction}

Meat chickens are called broilers or broiler chickens, or also often referred as broiler chicken, are a type of seed race, and are crossbred from a variety of chickenthat produce a high meat yield. Broiler chickens have ability and features that are bounded by age, characteristics of meat, treatment, feed, and maintenance. Broiler chickens are usually raised for 4-6 weeks with average weight of $1.3-2 \mathrm{~kg}$ and feed conversion of 1.6-1.9 (Murtidjo , 2003).

The development and success of breeding broiler chickens is effectd by the feed factor. Feed is a major factor in determining the success in breeding broiler chickens business because $60-70$ percent of total production cost is spent on the feed. For that reason, the feed as to meet the need of the broiler chickens, other than making sure that the feed does not contain any harmful chemical substance that will be dangerous for both poultry and consumers to consume.

To this day the development of chicken broiler farms still faces obstacles, among these obstacles are the high cost of feed. This is caused by the material used for feed rations such as corn and soybean are also consumed by humans, some feed materials such as fish flour and other mineral are important, which result in the price of the rations increase every year. On the other side, it is important to pay attention to the quality of the feed, because a quality feed will ensure the the availability of high-quality nutritional substances that are amenable to growth and the production of poultry. Efforts that should be done to reduce the cost of feed is to use a cheap alternative feed that is not dependent on harvest seasion, easy to get, and do not have to compete with men and have great nutritional potentials. 
Lamtoro leaves (Leucaena glauca) is the type of the leaves from leguminosa plant that can be found in rural areas that can be used for cattle, both ruminants and non ruminants. The abundant production of lamtoro leaves is not in line with the use. The low use of lamtoro leaves is caused by people's lack of interest in processing lamtoro leaves. Lamtoro leaves is a source of carbohydrates, protein and energy, that it can be used as a potential feed material. Lamtoro leaves contain $88,2 \%$ of dry ingredients (DM), 21,8 \% rough protein ( CP ) , 15,1\% coarse fiber (CF) , 3,1 \% ashes , 8,6 \% ether extract, and 50,7 \% BETN (Laconi and widiyastuti, 2010). Furthermore, it is suggested that the use of lamtoro leaves for poultry is limited to $10 \%$ because it contains mimosin that can be harmful for livestock.

The effort to overcome the limited the provision of lamtoro on poultry can be conducted by in dexifying mimosin contained in lamtoro leaves by heating under 70 degrees celsius for 15 mins (Laconi and Widyastuti, 2010). Another method is through fermentation. Fermentation can increase the level of digestion, add flavor and increase the vitamin and mineral content.

\section{Materials and Methods}

The study entitled the effect substituting basal leaves feed with fermented lamtoro leaves flour (Leucaena glauca) fermentation in rations on Feed Consumptions, Growth and meat chickens" with 60 day old chicks as study materialsStrains LoghmanMB 202, BR -1 feed produced by JapfaComfeed, Indonesia and fermented lamtoro leaves

This study consisted of 4 treatments with each treatment consisting of 3 remedials and each remedial involved 5 chicken. The design used in this research was Completely Randomized Design. The data obtained was analyzed using SPSS statistical analysis for Windows Release 15.0. The treatments in this study were as follows :

1. Control 1 (T0), chickens were fed concentrated feed without fermented lamtoro leaves flour yaitu.

2. Treatment 2 (T1), chickens were fed $95 \%$ concentrated feed and were given $5 \%$ fermented lamtoro leaves flour.

3. Treatment 3 (T2), chickens were fed $90 \%$ concentrated feed and were given $10 \%$ fermented lamtoro leaves flour.

4. Treatment 4 (T3), chickens were fed $85 \%$ concentrated feed and were given $15 \%$ fermented lamtoro leaves flour.

Table 1 . Feed study composition

\begin{tabular}{lcccc}
\hline Feed material & T0 & T1 & T2 & T3 \\
\hline 1. BR-1 (\%) & 100 & 95 & 90 & 85 \\
2. TDLF (\%) & 0 & 5 & 10 & 15 \\
\hline
\end{tabular}

Table 2.Feed Nutritional Value Research

\begin{tabular}{ccccc}
\hline \multirow{2}{*}{ Treatment } & \multicolumn{4}{c}{ Nutritional Value } \\
\cline { 2 - 5 } & BK $(\%)$ & PK $(\%)$ & SK $(\%)$ & ME (Kkal) \\
\hline T0 & 94 & 21 & 4 & 3000 \\
T1 & 90.60 & 20.83 & 4.36 & 2980 \\
T2 & 87.21 & 20.67 & 4.72 & 2960 \\
T3 & 83.82 & 20.50 & 5.08 & 2940 \\
\hline
\end{tabular}

Variables observed during the research covers food consumption, weight gain and feed conversion (FCR) as follows :

a. Feed Consumption, measured by the calculating the amount of food given deducted by the food left overs (gr/chick/day)

b. Growth, calculated by daily weight gain (gr/ chick/day).

c. Feed Consumption, calculated by comparing feed consumption to weight gain. 


\section{Result and Discussion}

\section{A. Feed Consumption}

The average broiler chickens feed consumptions to four different treatments are 82,79 (T-0); 84,24 (T-1); 84,01 (T-2) and 82,36 g/chick/day (T-3), with the average of $83,35 \mathrm{~g} / \mathrm{chick} /$ day

Table 3. Average of feed consumption of broiler chicken (gr/chick/day)

\begin{tabular}{ccccc}
\hline \multirow{2}{*}{ Replication } & \multicolumn{4}{c}{ Treatment } \\
\cline { 2 - 5 } & T0 & T1 & T2 & T3 \\
\hline 1 & 81,86 & 85,21 & 84,96 & 82,82 \\
2 & 84,04 & 83,70 & 82,75 & 82,68 \\
3 & 82,46 & 83,81 & 84,31 & 81,57 \\
\hline Average & 82,79 & 84,24 & 84,01 & 82,36 \\
\hline
\end{tabular}

Different, not significant (sig .116)

The statistics show that the average feed consumption to each treatment was different, not significant( sig.116 ). This means that the use of fermented lamtoroelaves flour to the feeddoes not affect broiler chicken feed consumption. This condition is caused by the concentrate substitution in fermented lamtoro leaves flourto $15 \%$ of concentrate still contain a relatively similar nutritional value compared to other treatments T0 (PK = $21 \%, \mathrm{SK}=4 \%, \mathrm{ME}=3000 \mathrm{Kkal}), \mathrm{T} 1(\mathrm{PK}=20,83 \%, \mathrm{SK}=4,36 \%, \mathrm{ME}=2980 \mathrm{Kkal}), \mathrm{T} 2$ $(\mathrm{PK}=20,67 \%, \mathrm{SK}=4,72 \%, \mathrm{ME}=2960 \mathrm{Kkal})$, dan $\mathrm{T} 3 \quad(\mathrm{PK}=20,50 \%, \mathrm{SK}=5,08 \%, \mathrm{ME}$ $=2940 \mathrm{Kkal})$. The nutritional values above still meets the standard need, which is 21-21 $\%$ of PK, and 2900-3100 Kkal of ME (Rudinunhalu, 2010). Dharmawan, dkk., (2016) state that feed consumption is affected by the food substance, besides health of the chickens, the temperature, the feed and stress in chicken.

The average feed consumptions in this research is $83,35 \mathrm{gr} / \mathrm{chick} / \mathrm{day}$ while consumption standard feed consumption for broiler chicken is $77,85 \mathrm{gr} /$ chick/day (PT .Indonesia JapfaComfeed , 2013 ) .This indicates that feed consumption in this study meets the standard of standard feed consumption as recommended by on the studies have in accordance with standard of requirement feed as recommended by PT. JapfaComfeed Indonesia.

\section{B. Daily weight gain in broiler chickens}

The average of weight gain of chicken broilers in each treatment was T0 $=42,89$, $\mathrm{T} 1=45,92, \mathrm{~T} 2=46,13$, dan $\mathrm{T} 3=42,90 \mathrm{gram} / \mathrm{ekor} / \mathrm{hari}$, with an average of $44.46 \mathrm{gr} /$ chick/day with an average 44,46 gr/chick/day.Nevertheless, when compared to the standard weight gain of a four week old chick Strain Loghman MB-202 which is $39.64 \mathrm{gr}$ / chick/day, then the substitution of concentrate with fermented lamtoro levaes flour up to $15 \%$ shows that a higher weight gain with an average of $44.46 \mathrm{gr} / \mathrm{chick} / \mathrm{day}$.

Table 4.Average weight gain in broiler chicken (gr/chick/day)

\begin{tabular}{ccccc}
\hline \multirow{2}{*}{ Replication } & \multicolumn{4}{c}{ Treatment } \\
\cline { 2 - 5 } & T0 & T1 & T2 & T3 \\
\hline 1 & 39,57 & 48,36 & 44,64 & 43,29 \\
2 & 45,18 & 44,82 & 46,29 & 44,25 \\
3 & 43,93 & 44,59 & 47,46 & 41,18 \\
\hline Average & 42,89 & 45,92 & 46,13 & 42,90 \\
\hline
\end{tabular}

Different, not significant(Sig .163)

Statistical test above result shows that the weight gain was different, unsignificant (Sig. 123)and it indicates that feeding fermented lamtoro leaves flour in feed up to $15 \%$ from the total basal feed does not affect to weight gain of chicken broilers. This could occur due to the feed consumed by the chickens in different treatments are different, unsignificant (Sig. 116) The feed consumptions in each treatment is $\mathrm{T} 0=82.79$, $\mathrm{T} 1$ $=84.24, \mathrm{~T} 2=84.01$ and T3 $=83.35 \mathrm{gr} /$ chick/day. Soeharsono (1976) states that consumption is greatly related to growth, in line with Tanwiriyah et al. (2006) that states 
that growth, indirectly is a growth in water, protein, and mineral and there is a close relation between the growth speed an the rations consumed in certain period.

Besides that, the quality of feed for each treatment is relatively the same so it would have the same effect on the weight gain. Dharmawan et al. ( 2016 )states that weight gain is affected by several factors as quality and quantity of the feed, the variety, sex, strains/furrow, behavior of the chickens, environment temperature, and the place that the chickens are raised.When the growth is at its best, the poultry will become versy sentitive to the nutritional level in rations (Wahju, 1992), and the more rations they consume, then the quicker they will gain weight (Tanwiriyah et al., 2006).

\section{Feed conversion}

The average broiler chicken feed conversion of broiler chickens in each treatment was $\mathrm{T} 0=1,94 ; \mathrm{T} 1=1,84 ; \mathrm{T} 2=1,82$; dan $\mathrm{T} 3=1,92$, with an average 1,88 . The statistical test shows that the feed conversion is different, (Sig.228).

\section{Table 6. Average Feed Conversion for Broiler Chicken}

\begin{tabular}{ccccc}
\hline \multirow{2}{*}{ Replication } & \multicolumn{4}{c}{ Treatment } \\
\cline { 2 - 5 } & T0 & T1 & T2 & T3 \\
\hline 1 & 2,07 & 1,76 & 1,90 & 1,91 \\
2 & 1,88 & 1,87 & 1,79 & 1,87 \\
3 & 1,88 & 1,88 & 1,78 & 1,98 \\
\hline Average & 1,94 & 1,84 & 1,82 & 1,92 \\
\hline
\end{tabular}

Different, not significant (Sig.228)

It indicates that the use of fermented lamtoro leaves flour as substitution for some feed does not affet feed conversion. Soeharsono ( 1976 ), states that the conversion of rations reflects physiological effects in making use of nutrition elements. Feed conversion affected by several factors, and among them are temperature of the environment, the speed of the feed until it is digested, the physical form and consumption of feed

\section{Conclusion}

1. The use of flour leaves lamtoro fermentation as a substitute for some feed concentrate to 15 percent of nutritional value meets normal standard of requirement of broiler chicken feed

2. The use of fermentedlamtoroleavs flour fermentation as a substitute for some concentrated feed does not affect the feed consumption, daily weight gain and meat chicken conversion feed

3. Fermented lamtoro leaves flour can be used as a substitute for some concentrated feed for chicken broiler

\section{References}

Dharmawan, H. S, S. Prayogi, dan V. M. A. Nurgiartiningsih. 2016. Penampilan Produksi Ayam Pedaging yang Dipelihara Pada Lantai Atas dan Lantai Bawah. Jurnal Ilmu-Ilmu Peternakan 26 (3) : 27-37

Laconi, E.B. dan T. Widiyastuti. 2010. Kandungan Xanthofil Daun Lamtoro (Leucaena leucochepala) Hasil detoksifikasi Mimosin secara Fisik dan Kimia. Jurnal Media Peternakan. Vol. 33 No. 1.Hlm : 50 - 54.

Murtidjo, BA., 2003. Pedoman Beternak Ayam Broiler.Kanisius, Yogyakarta.

Rudinunhalu.blogspot.com/2013/10/kebutuhan-nutrisi-pada-ayam-broiler.html?m=1

Soeharsono. 1976. Respon Broiler Terhadap Berbagai Kondisi Lingkungan. Disertasi. Universitas Padjajaran.

Tanwiriah, W, D.Garnida, I.Y. Asmara. 2006. Pengaruh Tingkat Pemberian AmpasTahu Dalam Ransum Terhadap Performan Entok (Muscovy Duck) Pada Periode Pertumbuhan). Skripsi. FakultasPeternakan. Universitas Padjadjaran.

Wahju, J. 1992. IlmuNutrisiUnggas. Cetakan ke-4. Gajah Mada University Press, Yogyakarta. 